\title{
An Exploratory Study of the Role and Identity of Alternative Media in Hong Kong: The Cases of Radical HK and WK News
}

Marta Soler Alemany ${ }^{1}$

Abstract : This paper explores the role and self-perception of alternative media in Hong Kong. Previous studies proved that alternative media plays a crucial role in social movements and as a counter-public agent of civil society. However, little attention has been paid on the alternative media self-perception in East Asia. Particularly, on its identity, potential influence on mainstream news agenda and its role on marginalized group's visualization.

${ }^{1}$ Marta Soler Alemany is a Sociologist (Universitat de Barcelona), an MSc. in International Relations (Institut Barcelona d'Estudis Internacionals) and a PhD Candidate in International Studies at Waseda University, Japan. The author is also an Investigator and Founding Member of the "Global Research Network on Comparative Territorial Autonomies" at the Academy of Hong Kong Studies, for the Education University of Hong Kong.

B CLIVATGE, número 8

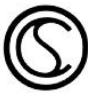


Two case studies based on in-depth interviews were conducted with alternative media organizations, mainly focused on workingclass struggles, WK News and Radical HK. This study contributes to media and political communication studies, and it has implications for civil society and media practitioners.

Keywords: alternative media, civil society, political communication, Hong Kong, working-class

Resumen: Este artículo explora el rol y la autopercepción de los medios de los medios de comunicación alternativos en Hong Kong. Estudios anteriores han demostrado que los medios alternativos tienen un papel crucial en los movimientos sociales y como agentes contrapúblicos de la sociedad civil. Aun así, es poca la atención que se ha prestado a la autopercepción de tales medios alternativos en el Este asiático; en particular, a su identidad, a su potencial influencia en la agenda de los noticiarios convencionales y a su papel en la visualización de grupos marginados. Nuestros dos estudios de caso, basados en entrevistas en profundidad, se ocupan de medios de comunicación alternativos centrados fundamentalmente en las luchas de la clase trabajadora: WK News y Radical HK. El presente estudio contribuye al campo de los estudios los medios y la comunicación política, y posee implicaciones para las personas que participan en la sociedad civil y en los medios de comunicación.

Palabras clave: medios de comunicación alternativos, sociedad civil, comunicación política, Hong Kong, clase trabajadora

B CLIVATGE, número 8

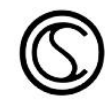


Resum: Aquest article explora el rol i l'autopercepció dels mitjans de comunicació alternatius a Hong Kong. Estudis anteriors han demostrat que els mitjans alternatius tenen un paper crucial en els moviments socials i com a agents contrapúblics de la societat civil. Malgrat això, és poca l'atenció rebuda per l'autopercepció d'aquests mitjans alternatius a l'Est asiàtic; en particular, la seva identitat, la seva potencial influència en l'agenda dels noticiaris convencionals i els seu paper en la visualització de grups marginats. Els nostres dos estudis de cas, basats en entrevistes en profunditat, s'ocupen de mitjans de comunicació alternatius centrats bàsicament en les lluites de la classe treballadora: WK News i Racical HK. El present estudi contribueix a l'àrea dels estudis dels mitjans i la comunicació política, i té implicacions per a les persones que participen en la societat civil i els mitjans de comunicació.

Paraules clau: mitjans de comunicació alternatius, societat civil, comunicació política, Hong Kong, classe treballadora

\section{Introduction}

Previous studies have focused on the alternative media role as a counter-public agent of civil society and a key platform for activism, social movements organization, citizen journalism and public debate (Atton, 2002; Downing, 2001; Yung \& Leung, 2014; Lee, F., 2015; Lee, F., 2019: 176-182). Most of the research has

B CLIVATGE, número 8

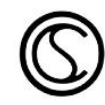


examined the communication tactics of major social movements such as the Arab Spring, the Indignados in Spain, the Occupy Movement in the US or the Umbrella Movement in Hong Kong. However, little attention has been paid on the role of alternative media during protests and strikes having less media attention, especially from working-class collectives such as farmers, fishermen, restaurant workers or migrant workers. Similarly, previous literature has rarely considered how alternative media platforms perceive and define themselves, and if they do, they are focused on western cases and restricted to mainstream media. Previous literature has also rarely analyzed the alternative media potential to influence the mainstream news agenda (Lee, F., 2019: 179-180).

Before moving ahead, a clarification of the term is needed. Alternative media are non-institutionalized platforms and any activity conducted out of the conventional or mainstream media framework (Atton, 2002; Downing, 2001) that challenge dominant political, economic, and media power (Lee, F., 2019: 176; Meyers, 2008). They have a smaller size of audience and are more likely to attract politicized and critical citizens (Leung \& Lee, 2014: 354), considering that online news media constitute platforms for public debates and opinion expression and do not just provide public affairs information (Lee, F., 2019: 170). Similarly, most independent media are "politically-inclined" (Iam-Chong, 2009: 59). Generally, alternative media faces various structural and organizational limitations and challenges, for instance, the lack of financial resources and full-time personnel.

B CLIVATGE, número 8

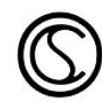


Hong Kong is a relevant case due to its particularities and elements of continuity and change that can be related to other cases such as Taiwan. Hong Kong is a "hybrid regime", in-between liberal authoritarianism and electoral authoritarianism (Fong, B., 2017: 25). According to the Reporters Without Borders' World Press Freedom Index, since the Handover in $1997^{2}$, there has been a decrease in free journalistic expression. Recently, we have seen various aggressions to journalists covering events, especially during the 2019 anti-extradition protests, also called the WaterRevolution. Besides, both journalists and citizens perceive selfcensorship as increasingly severe (Lee, F., 2015) and there has been a turn towards online news consumption and "more than 80 per cent of the population use online sources for news" (Chan et al., 2018: 118).

Additionally, there has been a rise and transformation of the counter-public sphere in Hong Kong and the growth of alternative media readers and practitioners. Alternative media are used as a way to access independent news since there is a general dissatisfaction with the mainstream press (Chan et al., 2018: 118). The Internet, political events and social developments have facilitated the rise of digital media platforms and alternative media news sources such as In-Media, Initium Media, Stand News or Hong

2 On July 1 in 1997, Hong Kong, which, was under the United Kingdom administration until that moment, was returned to the control of China. There was a transfer of sovereignty over Hong Kong, and it became a Special Administrative Region of the People's Republic of China, although it kept governing and economic autonomy.

B CLIVATGE, número 8

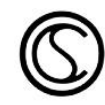


Kong 01 (Lee, F. 2019: 176). Concretely, this has been a consequence of the advancement of the Internet and digital technologies that facilitated the lowering of the costs of production and distribution (Lee, F. 2019: 176-181). Indeed, Hong Kong has high levels of Internet, broadband, social media, and mobile penetration (ITU, 2019). At the same time, there is no specific law addressed to regulate independent media in Hong Kong and running websites does not require any registration. However, the Control of Obscene and Indecent Articles Ordinance monitors print and online media. According to the ordinance, a judiciary body called The Obscene Articles Tribunal will decide if an "article" submitted to the tribunal is "indecent" or "obscene" (Iam-Chong, 2009: 62-63).

On the other hand, in the last decade, there has been a decline in civil liberties such as associational and organizational rights and human rights in Hong Kong, including labour rights (Freedom House, 2019; Amnesty International, 2019; Reporters Without Borders, 2019). Besides, the working-class struggles are not often or extensively reported in mainstream media and, many people in Hong Kong and elsewhere are not aware of their situation. Furthermore, it should be highlighted that Hong Kong residents have the right and freedom to form and join trade unions. Since 1968, the Employment Ordinance (chapter 57) protects employment conditions and labour rights such as days off, paid holidays and annual leave, sickness allowance, maternity and paternity leave, termination of employment contracts and protection against anti-union discrimination, among others. At the

B CLIVATGE, número 8

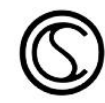


end of 2018, there were 908 trade unions registered under the Trade Unions Ordinance. The Labour Department (2019) handled 13.781 labour claims and disputes, most of which were related to disputes on termination and wages. During the same year, the department handled five strikes.

In this context, various questions arise. What is the role of alternative media in contemporary Hong Kong? Can alternative media play an influential role in the mainstream media news agenda? To what extent do they contribute to the visualization of the working-class struggles? To what extent do they offer alternative visions? This paper explores the potential capabilities and the limitations of alternative media platforms in Hong Kong through a two-case study. The first section introduces previous studies regarding the conceptualization and the role of alternative media. The second part explores the qualitative research methods based on the case study of Worker News (WK News) and Radical Hong Kong (Radical HK) while presenting the case selection and data collection processes; followed by the analysis process and the findings. The paper ends with a conclusive discussion.

\section{Literature Review}

It has been proved that alternative media challenges the traditional practices of mainstream media and provide critical social debates (Atton, 2003: 207; Iam-Chong, 2009). Alternative journalism or alternative online media structurally opposes "hierarchical, elitecentred notions of journalism as a business" (Atton, 2003: 268). It can also be an essential source of information for movement

B CLIVATGE, número 8

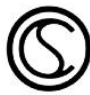


supporters and participants in particular protest campaigns (Lee, F., 2019: 180). Various studies found a direct connection between Internet alternative media usage and protest participation (Cha, 2017; Leung \& Lee, 2014). Similarly, the history and development of alternative media cannot be separated from social movements, political ideology and processes of democratization (Lee, C., 2003: 172; Iam-Chong, 2009). Alternative media has been acting as an agent of political change (Lee, C., 2003.).

The initial Internet-based media projects in western countries started in 1985 in the US and UK (Atton, 2007: 59). Most of the early independent media centres were first established to report on the emerging large-scale mobilizations against neoliberal globalization (Atton, 2004: 81). For example, Indymedia - also called Independent Media Center - was founded in London and Sydney during the 1999 Carnival Against Capital when the G8 summit in Germany was celebrated. Its main goal was to report on the protests against the World Trade Organizational Ministerial Conference in Seattle and became part of the global justice movement.

In East Asia, the earliest Internet-based media projects started during the same period, considering that social movements and democratic transitions cannot be separated from the alternative media evolution. Media liberalization is a precondition to full democratization. However, although the media are virtually free from state censorship, market forces are indirectly but also significantly controlling them (Lee, C. 2003: 172). Taiwan is a crucial case reflecting these facts because it has experienced a

B CLIVATGE, número 8

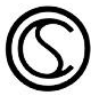


transition to democracy, since the 80s, and a media liberalization process. In both processes, mainstream and alternative media or "guerrilla media" played a crucial role in the story of democratic transition, being especially active from 1976 to 1995 (Lee, C., 2003: 163-171).

For example, two principal Dangwai ("outside the party") political magazines to mobilize grassroots support, was the Taiwan Political Review and the Formosa Magazine (Song, 2009: 145). According to Lee, C. (2003: 163-172), the guerrilla media were understood as "weapons of the weak" acted as agents of political change, giving voice to opposition forces which were challenging the dominant system and ideologies. Another relevant case is Malaysia where alternative media - mainly consisting of newspapers and magazines published by NGOs, activists, and opposition political parties such as Aliran Monthly and Harakah have rapidly grown since the 80s (Ling, 2003: 290). The role of alternative media is essential in the country because it offers critical, oppositional and a wide variety of viewpoints. Nevertheless, government control over alternative media remains tight (Ling, 2003: 299).

In Hong Kong, before the 1990s, non-profit civil groups and organizations ran numerous independent publications. At the same time, ongoing political confrontation has been affecting independent media's evolution. However, independent online media with a political consciousness did not emerge until 2003 when over 500,000 people joined the July $1^{\text {st }}$ rally against the implementation of the National Security Bill. Since then, the

B CLIVATGE, número 8

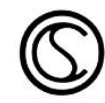


number of citizens exchanging information and creating satirical and critical content against the Government through the Internet has multiplied. "In part, such practices paved the way for online mobilization" (Iam-Chong, 2009: 54-67). Another factor that has been influencing media and political communication dynamics is that Hong Kong has experienced a significant transformation of identity politics in recent years. The Umbrella Movement in 2014 strengthened the Hong Kong identity construct because it was an attempt to defend the citizens from external and internal domination (Ortmann, 2018: 127).

According to Lee, F. (2019: 176-177) there were two waves of alternative media in Hong Kong. The first wave emerged in 2004 - with alternative Internet radio such as People's Radio Hong Kong (PRHK) or DIYHK as well as commentary websites - mostly due to the 2003 social mobilization and overall political consciousness that the protest against the National Security Bill exemplified. During this period, In-media Hong Kong was the earliest and most well-known platform. However, alternative media did not achieve a high level of social prominence and influence because they had a small audience and budget. The second wave started around 2012 and 2013 with the appearance of news and commentaries websites such as House news, Passion times or VJMedia. There were three main reasons for this second emergence: a) the continual worsening of the problem of self-censorship and the further contraction of spaces for free expression in the mainstream media; b) the popularization of social media as platforms for political

B CLIVATGE, número 8

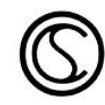


communication; and c) the continual growth of social protests in Hong Kong (Lee, F., 2019: 178-179).

Yung and Leung (2014: 88-99) assume that alternative online media plays diverse roles in civil society. It provides alternative information, serves as an alternative public sphere, a platform for social activists and civil society organizations for information-dissemination, information-exchange, specific campaign or event-advertising and networking; and it also acts as an initiator of public discourse and as an agent of civil society activism. Lee, F. (2019: 170) highlights the critical role of alternative media in "proposing" items onto the news agenda. A clear example of their impact was in 2013 when Prof. Benny Tai, one of the key figures of the Occupy Central in Hong Kong, published an article on the Hong Kong Economic Journal about the idea of organizing a pro-democracy civil disobedience campaign to pressure the local Government. After In-media, a pro-democracy alternative media platform, published that interview, the article started to get public attention. This action generated heavily debated online discussions, stimulated social discussion about Occupy Central and lead to additional coverage in the mainstream press (Lee, F. 2019: 180).

In contrast, various authors asserted that the power of social and digital media is overestimated (Portes, 1998) and that a higher alternative media usage does not involve more civil society actors in defending civil and democratic rights (Lee, F., 2019: 181). Similarly, the audience size of alternative media is small (Leung \& Lee, 2014), while partisanship influences media choices (Stroud,

B CLIVATGE, número 8

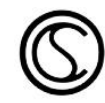


2011). People who are politically active or interested in politics are already reading alternative media or are being exposed to political sources (Krueger, 2006). Accordingly, political activism becomes "self-reinforcing" (Tang, 2019: 191). In Hong Kong, democracy supporters are more likely to be the audience of pro-democracy Internet alternative media (Leung \& Lee, 2014: 353). Nevertheless, people who share the orientation and perspective with specific alternative media platforms are not the only ones exposed to their content (Leung \& Lee, 2014). On the other hand, Downing (2001: 15-16) claims that radical media "disrupts the silence, to counter the lies, and to provide the truth." However, (the) 'alternative' is relative because it can become the mainstream depending on the time and place (Yung \& Leung, 2014: 99).

Hence, the alternative media can play an essential role in a partially-democratic system and a context of decreasing press and media freedom and governmental legitimacy as well as a growing socio-political crisis. The case of Taiwan and Malaysia show the importance of the alternative media role in "opening up media spaces, ushering in the process of political democratization" (Lee, C. 2003: 164), and reinforcing civil liberties and critical thinking.

\section{Research Methods}

This study employed a qualitative analysis based on a case study approach (Creswell, 2007), providing insights from the editors' perspective and helping understand the role of alternative media in Hong Kong better. Face-to-face semi-structured in-depth interviews were conducted in June 2019 with the Chief Editors

B Clivatge, número 8

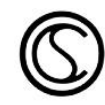


from two alternative media platforms in Hong Kong: Radical HK and WK News. Concretely, for section 4.3. various articles and videos published were evaluated in both alternative media websites and various social media sites to understand the audience reaction. For section 4.4. the number of parts covered on their websites was checked. Both interviews were conducted in English. The interviews were interpreted considering that "the real story of alternative media platforms is what happens behind the surface of the computer screens" and what captures their subjectivity, internal structure and dynamics (Atton, 2004: 79). The choice of interviewees and how questions are formulated follow the "criteria of representativity" (Della Porta, 2014: 250), and this will be explained in the following sections.

\subsection{Case selection}

These two cases were selected for various reasons. Firstly, they are part of the second wave of alternative media in Hong Kong, after 2012, helping to understand socio-political and media transformation; especially considering the increasing selfcensorship among journalists, decreasing spaces of free expression in the mainstream media, the rise of social media as platforms for political communication and the increasing of social protests in Hong Kong (Lee, F., 2019: 178-179). Secondly, they have various characteristics 3 In common. They are both mainly focused on the working class struggles and grassroots movements, defining

3 This information has been extracted from both in-depth interviews and the manifesto and profile written on their official websites.

B CLIVATGE, número 8

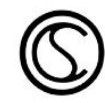


themselves as an activist and community media, with a small team (1 to 5 ) of volunteer reporters and activists. They have a leftist orientation and aim to show an alternative perspective of reality and contribute to social change. Most articles are written in Cantonese, although in the case of Workers News, $5 \%$ are written in English. The profile of readers is young (from 20 to 40 years old), with a similar number being male or female, mostly from Hong Kong, Taiwan and in a lower scale, from Mainland China ${ }^{4}$. In the case of Radical HK, they also have some readers from Malaysia.

WK News was founded in 2013. They mainly focus on the working-class and grassroots movements. Their main goals - stated by the chief editor during the interview and also stated on their website $^{5}$ - are to engage, inform and empower the working-class community in Hong Kong by helping them know more about their rights and working conditions as well as, encourage student organizations and other sectors to participate in strikes. They define themselves as activist and community media. They interview activists, focus on reporting and follow up on specific protests, and marginalized issues and this will be described in the analysis and findings section.

Regarding their financing methods, they receive a membership fee while relying on donations from the public and

\footnotetext{
${ }^{4}$ Despite the Chinese Government high control and censorship, many Chinese netizens use VPN services that allow them to pass over the Great Firewall. While they are connected to a VPN, they can have all information and data traffic going through it.

${ }^{5}$ Available at http://wknews.org
} 
small project funds. However, they do not want to depend on crowdfunding as a source of income since they believe it would restrict their independence due to demands and expectations from possible downers. Concerning their presence on the Internet and social media, they have an official website, Facebook and Twitter account as well as a YouTube channel. As we can see in table 1, they are most active on their official website and Facebook account. They cover different topics related to the working class and labour movements such as janitorial workers and domestic migrant workers and they also report on marginalized groups life stories.

Radical HK News was established in 2015. They focus on various working-class and grassroots movements, and on the "land justice cause" 6 as well as, the hearing challenged community in Hong Kong. For example, they provide simultaneous sign language translation in some events. They have four primary purposes stated by the chief editor during the interview and also stated on their website ${ }^{7}$ a) to record the issues of the working class, b) make marginal issues visual, c) create a database based on their investigations and the reporting from NGOs, and d) help to organize the movements related to the working class in Hong Kong. They define themselves as activist and community media.

${ }^{6}$ This cause is based on the preservation of the natural environment, the right of accommodation for everyone, the eradiation of the real estate tyranny, the defence of indigenous villagers and developers, the democratic land planning, among other objectives.

${ }^{7}$ Available at https://radicalhk.com

B CLIVATGE, número 8

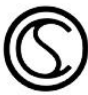


Regarding their financing methods, the platform relies on donations from the public when they need some specific materials such as cameras or computers. They also rely on crowd funding when necessary. Regarding their presence on the Internet and social media, they have an official website, Facebook, Twitter, Telegram and Instagram account as well as a YouTube channel. As we can see in table 1, they are most active on their YouTube channel, Facebook account and the official website. They cover different topics related to the working class strikes, situation and life stories such as fishermen, farmers or restaurant workers.

Thirdly, they both collaborate and have built an essential network within various NGOs related to different groups of the working class in Hong Kong. It is essential to highlight that different groups within civil society and activism organizations use alternative media platforms to report and exchange information, do networking, express their stands on different issues and outline their activist actions (Yung \& Leung, 2014: 94). All these characteristics make both cases enlightening in order to explore alternative media's role and relationship with civil society in contemporary Hong Kong, in the short-term and long-term. It is acknowledged by the author that the two cases analyzed represent a small portion of the overall alternative media landscape and community in Hong Kong and worldwide. However, they are representative cases that help to understand socio-political and communication transformations as well as alternative media characteristics and dynamics. Besides, they can contribute to media

B CLIVATGE, número 8

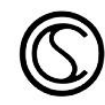


theories and enrich empirical/qualitative analyses. Therefore, they should not be underestimated.

Table 1. WK News and Radical HK communication portals

\begin{tabular}{|c|c|c|}
\hline & WK News & Radical HK \\
\hline Official Website & 31.419 views & 391.978 views \\
\hline YouTube channel $^{8}$ & 103 subscribers & 785 subscribers \\
\hline Facebook account & $\begin{array}{l}20.975 \text { likes } \\
21.241 \text { followers }\end{array}$ & $\begin{array}{l}12.405 \text { likes } \\
13.836 \text { followers }\end{array}$ \\
\hline Twitter account ${ }^{9}$ & $\begin{array}{l}1.481 \text { tweets } \\
140 \text { followers }\end{array}$ & $\begin{array}{l}246 \text { tweets } \\
35 \text { followers }\end{array}$ \\
\hline Telegram account & $\begin{array}{l}\text { Non-existent/not } \\
\text { found }\end{array}$ & 199 members \\
\hline Instagram account & $\begin{array}{l}\text { Non-existent/not } \\
\text { found }\end{array}$ & \begin{tabular}{|l|}
91 posts \\
626 followers
\end{tabular} \\
\hline
\end{tabular}

Source: Compiled by the author.

Note$^{1}$ : Data as of March 2020.

\subsection{Data collection and analytical approach}

Two semi-structured interviews were conducted face-to-face on June 27 2019, during the first phase of the Anti-extradition Movement. It was one day before the celebration of the G20 Osaka summit, and various groups and activists in Hong Kong such as the

8 As of this writing, WK News YouTube channel is inactive.

${ }^{9}$ As of this writing, WK News and Radical HK Twitter account are inactive.

B CLIVATGE, número 8

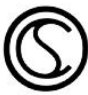


pro-democracy organization Civil Human Rights Front (CHRF) were organizing meetings and protests in order to raise global awareness regarding the political situation in Hong Kong. One of the interviews was conducted in the WK News media's office in the Kowloon area and the other one in a cafeteria on Hong Kong Island. The length of the interview was around an hour each. The interviews comprised questions regarding their mission and working methods, financing methods, their perception about the future of alternative media role in Hong Kong, press and media freedom and the political and social situation conception as well as their impact on news media and audience in a broad perception.

The interviews were transcribed, and the analysis process was based on a manual descriptive coding method to explore the data's essential topics (Saldaña, 2009: p.70). In both cases, various codes, categories and themes were defined. However, this study chose to represent the data in a descriptive and deliberative way, focusing on the main themes found. Concretely, it established five patterns and has developed naturalistic generalization from analyzing the data. These generalizations can be applied to other cases and individuals (Creswell, 2007: 153-163). The cases and results were validated by using multiple data sources (Creswell, 2007: 79; 225): a) two in-depth interviews which were the core of the analysis, complemented with, b) the content evaluation and the number of viewers of 229 videos in the case of Radical HK; and c) the content evaluation and the number of readers of 401 articles/reports in the case of WK News.

B CLIVATGE, número 8

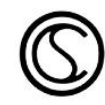


Regarding Radical HK, all videos were published on their YouTube channel from 2015 until March 2020. Written articles/reports were not analyzed because the reaction of readers cannot be verified and because the most relevant content of the platform is published in the format of videos. However, regarding WK News, the articles/reports from the section called "Worker News" (Wéi gōng xīnwén) published on their official website, from 2015 until March 2017, were evaluated. The number of readers in 2013 and 2014 was deficient; this is why the articles and reports evaluation starts from 2015. Also, the number of readers information is available online on those dates, but, after 2017, just the information referring to the number of likes is accessible. The author considers that the number of likes cannot determine the actual number of readers. Therefore, the articles from 2018 until 2020 were omitted. On the other hand, it must be highlighted that just the videos and articles/reports that received a higher audience reaction, considering the number of views and readers, are described in the following section. Concretely, they served to complement the third pattern (the potential influence on mainstream media news agenda) by giving concrete examples.

\section{Analysis and findings}

Based on the two in-depth interviews and previous studies, this research found five interrelated patterns that reveal the nature and potential role of alternative media in Hong Kong: a) sense of selfidentity, b) intermediary connections, c) potential influence on 
mainstream media, d) specialization and time control and, e) joint resistance.

\subsection{Sense of self-identity}

Alternative media platforms have a strong sense of self-identity based on the notion of "resistance identity" because the actors that are being dominated by the system produce it (Castells, 2010: 90). It is also related to the identity and citizenship construction in Hong Kong (Ngok, 2018: 34) and a strong sense of a united civic community against recolonization from Mainland China (Law, 2018: 32). The interviews reveal how protests, social movement participation and the empowering mission of the platforms have influenced their identity construction, considering that "alternative media journalists value their normative responsibilities more" (Harlow, 2017: 117-135). Interviewee B makes the following assertion:

"To empower is the most important mission for us. That's why we regard ourselves as activists; we are not just reporting, we are not just journalists we are empowering them (the workingclass protesters). One of the differences is, for example, in the protests, we will not wear the sign of press, just, arrest me. We are activists." (Radical HK, June 27, 2019)

Existing definitions include the inherent characteristics of being non-mainstream, economically independent as well as being an activist and system-challenging media offering news and narratives from the activism perspective (Atton, 2004: 75). Meyers

B CLIVATGE, número 8

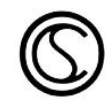


(2008) argues that alternative media practitioners have different self-perception than professional media workers. Other authors claim that alternative online media is structurally radical because it opposes "hierarchical, elite-centred notions of journalism as a business" (Atton, 2003: 268). One of the elements that various definitions and analysis fail to mention is that there is often a selfreflection asserted by alternative media editors. They face the internal line between journalism and physical participation with activism and involvement. For instance, they assert that some of the members might be more comfortable keeping some physical distance from social movements. According to interviewee A:

"One of the characteristics of alternative media like us is that we regard ourselves as activists instead of just journalists. Maybe some of us will become half organizers because sometimes we will think that kind of work is more important instead of writing articles. But, this kind of attitude is also debatable, both internally and externally. Some of our members may not be that active involving in the actual struggle. Some others will think that is not the role of journalists to be so close with the people." (WK News, June 27, 2019)

In addition, they have an anarchic ideology not just aiming to keep their independence from economic and governmental pressures but also, from professional organizers or activists and public pressure. Interviewee A expresses the following view:

"I always think that ordinary people should do social movements instead of participation done by paid professional and

B CLIVATGE, número 8

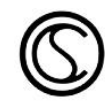


organizers or activists. If the social movement is specialized and professionalized, it means that ordinary people only have very limited space to participate and have limited power to decide what is happening. And that's why we collect our money to do that and to rely on our own money instead of public donation. With this kind of financing, we do not need to do a lot of things to appeal to public eyes." (WK News, June 27, 2019)

Another element is their commitment, which is intrinsic to their sense of identity. Interviewee B highlights that: "We believe that our reports are much better than some of the traditional media because at least we are doing something that starts in our own heart." (Radical HK, June 27, 2019). Hence, alternative media identity construction and consolidation go through social movement participation. It is also characterized by a self-reflection on keeping their journalist side apart from their activism and physical participation. The anarchic factor is equally essential for their distinctiveness and existence since it is adopted to avoid four key sectors of pressure (economic, governmental, professional organizers and activists and the public).

\subsection{Intermediary connections}

Alternative media becomes an intermediary between workers and society and among the workers themselves, based on common beliefs and values influencing the world's perception of civil society. This pattern is related to the sense of identity discussed previously and the theory of political culture. This theory provides a framework for political change and helps to create shared values

B CLIVATGE, número 8

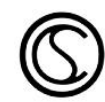


and beliefs among people, which serve as a link between citizens and government. Political culture also influences how we see the political world and what citizens value, for example, press and media freedom. It also influences how you feel regarding your fellow citizens and government performance (Almond \& Verba, 1963).

Nevertheless, in a partially-democratic system with nonpolitical structures implementing electoral reforms or major political changes as well as, relative participation from citizens in the political system and the decreasing press and media freedom process; alternative media's intermediary role becomes relevant. In this type of political regime and a liberal and capitalistic economic system like Hong Kong, many sectors do not have political representation, they are not conscious about violations of their fundamental rights, and their struggles are socially invisible. According to Interviewee A:

"We do many interviews with workers from different sectors. There are two aims. First, it is for the workers in those sectors to identify their problems and then getting inspired by what their co-workers said and think what should they do to improve the situation. Second, for the workers in different sectors to understand each other because in a lot of cases people think they are well paid so they should not complain too much. We try to engage people and put much emphasis to follow up with the worker's struggle in Hong Kong." (WK News, June 27, 2019)

B CLIVATGE, número 8

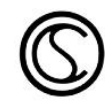


The alternative media actions are related to processes of democratization and the socio-political situation (Lee C. 2003: 172; Iam-chong, 2009). They also cannot be separated from their will to influence the political agenda and decision-making, while being within their conscience of limitations. Interviewee B asserts that:

"In Hong Kong, you have your press freedom, but you cannot help the groups because we do not have the supporting democratic system. Even our society is not really a democracy. In this kind of society, if you just do some reporting, this is non-sense (...) We are an activist media; we really want to change some policy. We want to organize those groups (working-class groups). Our report is empowering them, helping the organizers." (Radical HK, June 27, 2019)

Hence, being an intermediary between workers and society and among the workers themselves is an intrinsic characteristic, which is often omitted from alternative media conceptualization and analyses. It is important to highlight that a vibrant civil society, supported and connected through alternative media, can contribute to democratic transition (Yung and Leung, 2014: 85), and the reinforcement of civic rights.

\subsection{Potential influence on mainstream media news agenda}

Alternative media platforms have the potential to influence the mainstream media news agenda (Lee, F., 2019: 181). This section explores basic elements of the potential influence of alternative media platforms based on the interviewee's testimonies. However,

B CLIVATGE, número 8

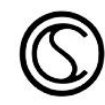


it will not corroborate the real impact on the media news agenda. It will offer an exploration on this matter with a descriptive focus. The main argument is in line with the notion of "agenda-setting" which refers to issues highlighted by the media and the transfer of the importance of these matters to the public. Within the theory of agenda-setting, three areas are related and influenced by different factors involved in the communication process: the media, the public and politics (Oller, 2014: 50-51). This paper is focused on the interaction between alternative and mainstream media, which is need it for further study the relationship between the media, the public and politics. Dearing and Rogers (1996: 20) note that the audience will give a general relevance to an issue in terms of the coverage that has been done in the media. Both interviewees claim that influencing mainstream media news agenda happens rarely and just in particular cases, but they provide some examples.

For example, Interviewee A points out that after they covered, investigated and reported on the cleaning worker strike from the Man Shun Hong Kong and Kowloon Cleaning Company's workers, during December and January in 2017, the mainstream media also started to cover it. The protests originated because the workers were denied severance payments after being "forced" to sign voluntary resignation agreements by the company, putting them in a vulnerable situation. There are various articles related to the topic that could be found in mainstream and independent media platforms in 2017 such as, the Apple Daily, the South China

B CLIVATGE, número 8

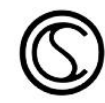


Morning Post or the Hong Kong Free Press 10 , while other alternative media platforms such as the Stand News or HK01 also had articles published regarding this topic. However, interviewee A insisted: "We were the first ones to cover it, and we heard from a lot of mainstream journalists that they were following our website."

Another example, is the sand mining and land reclamation problem in Hong Kong, affecting the Runway of the Hong Kong airport and the artificial island in East Lantau; concretely, the socalled Lantau Tomorrow Vision plan 11. In 2017, Radical HK denounced the amount of money wasted on it as well as the environmental impacts of the project. Interviewee B claimed that after they covered it, various mainstream media outlets also followed up on the case, pointing out that: "Some of our readers are journalists from other media outlets. They look at our stories." Although no specific media outlets were mentioned during the interview, this news can be found in Apple Daily and South China Morning Post, among others around the same dates.

On the other hand, alternative media groups have their way to make an impact, and they avoid doing the same kind of stories as other media platforms in order to keep their authenticity. They do

10 Available at: https://staging.hongkongfp.com/2017/12/28/ive-trickedhousing-estate-cleaning-workers-strike-hk1m-alleged-outstanding-

payments/

11 This plan includes to build 1,700 hectares of artificial islands in the waters around Kau Yi Chau and Hei Ling Chau between Lantau and Hong Kong Island. It will also include near-shore reclamation and a cross-sea transport network linking the islands to Lantau, Tuen Mun and Hong Kong Island (Zhao, 2019).

B CLIVATGE, número 8

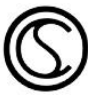


not have the will to become mainstream or to have an influence on mainstream media by focusing on reaching more readers. They want to keep their alternative nature by focusing on content and different life stories and protests from the working class. Interviewee A insisted on "we are not making some topics hot. Instead, we are finding special perspectives on a hot topic." Interviewee B pointed out that: "We cannot get the mass because we are not big enough. This is the cause and effect. If we do mainstream, we will be more focusing on demand."

Similarly, both interviewees mentioned how there is a trend among alternative media platforms to cover hot topics in order to reach a higher audience implying a negative consequence in keeping to the 'alternative' form. Interviewees insist on the quality of their stories as part of their strength and potential influence on reaching a major number of readers and mainstream media. For instance, Interviewee B gave an example regarding a well-known alternative media platform:

" $\mathrm{X}_{1} 12$ is a big media; they have 700 reporters. They started focusing on marginal issues, and some other media discovered that they had to report marginal topics to build up their brand. Not because they really care about those people (...) The likes and forums that the platforms have are not the most important. The most important thing is the story; your content is the key. I believe that if we do better our content, it will reach many people naturally." (Radical HK, June 27, 2019)

12 The author decided not to mention the name of the platform because it is not relevant for this study.

B CLIVATGE, número 8

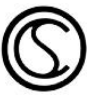


In order to complement the interviewee's perspective, this study has looked at the audience reaction to various videos and articles/reports published on both websites and SNS. In the case of Radical HK, the 229 videos were evaluated - from 2016 until March 2020 - 15 videos have more than 1.000 views. As of this writing, one of the videos that has reached a higher audience, with more than 126.000 views on YouTube in $2016^{13}$, was about the case of a farmer from Ping Che village in the Ta Kwu Ling area in Hong Kong who introduced a more sustainable alternative of hydroponics of a fish-vegetative symbiosis into rural and local areas which has many benefits for the local economy, community and ecosystem. In the video, he expresses the aim to teach it to other farmers, helping them to become a sustainable community and economic model.

In the case of WK News, among the 401 articles/reports that were evaluated from 2013 until 2017, we can find more than 30 articles/reports that reached a higher number than 10.000 readers. One of the cases reported with a high number of readers, 94.18414, was written in June 2017. One of the restaurants of the Chou Fook Royal Banquet chain closed and 11 kitchen workers did not get paid on time. The workers then sought assistance from the Hong Kong Chefs Association, a non-profit organization. After a round of negotiations, the workers recovered half a million of severance payments that the restaurant owned them.

13 Available at: https://www.youtube.com/watch?v=pLmyPCIMvAU

${ }^{14}$ Available at: https://wknews.org/node/1469

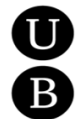

CLIVATGE, número 8

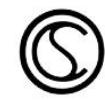


Therefore, alternative media platforms have the potential to reach a higher number of readers and thus, the potential to influence mainstream media. However, based on both interviews, the alternative media wants to keep a coherent impact and uniqueness, focusing on the stories and the content related to their mission, in this case, the working-class struggles.

\subsection{Specialization and time control}

Alternative media is a specialized media having the time to control the development of their news, videos, content and reports. This pattern is related to the framing theory and the idea of agendasetting described above. Studies of agenda-setting have stimulated the debate on priming and framing (Weaver, McCombs \& Spellman, 1975; Coleman et al., 2009). Generally, mainstream media journalists have to strictly follow their companies timing and agenda-setting regarding current news and updates and in many cases, do not have time to dive deep into specific topics. Similarly, journalist's approaches are influenced by media agendas, both in public and in the policy. These agendas, in turn, depend on the role played by media in respect to the information that they produce (Oller, 2014: 61). Another element is the understanding of the journalist as a gatekeeper based on the basic premise of selecting the news that appears in the media and filtering out useless information (DeGeorge, 1981: 219-220).

Apart from sports and social press, among others, most mainstream and mass media report on different current topics of interests for a wide variety of readers. They have different news

B CLIVATGE, número 8

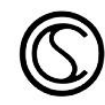


sections in their online websites and SNS covering a variety of topics such as society, economy, world news, culture, entertainment, among others. However, alternative media platforms are focused on specific topics and for specific readers. WK News official website contains six sections specializing in the working class, such as working life or the work industry. Radical News contains nine sections related to workers and marginalized collectives, including a project from the Land Justice League ${ }^{15}$ and one section regarding sign language policies. According to interviewee A:

"One of the most important differences is that (mainstream) media is like an encyclopedia. It contains everything, local news, international news, entertainment... But now, there are more and more media, which is specialized, in specific issues like literature, culture... This kind of change is very beneficial for both the media and the public because the public can have the chance to access higher-quality information. The other benefit is that we do not need to appeal to all kinds of audience." (WK News, June 27, 2019)

Also, their primary focus is on accomplishing their objectives not only on reaching a large number of readers and not being controlled by the market system. This is another element that allows them to deep in different topics, being free from the

15 It is a Hong Kong activist group that co-opts other social groups who are interested in the "land justice" cause described in section 3.

B CLIVATGE, número 8

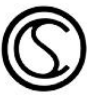


pressure of timing, deadlines and strict news agendas. According to interviewee B:

"Our most important mission is first to record the marginal issues. You can see that most of the protests or most action usually there are many media but, maybe just one or two media will focus on marginal topics and even if they do, they will be on screen every few minutes or seconds. Our record is vital for them, for the workers, for the people who are into action. Not only for the readers. They will grow up when they attend this kind of protests and action. We have to say that even not many people or media focus on that kind of issues, the record is still vital." (Radical HK, June 27, 2019)

At the same time, being specialized media allows them to keep their originality. As Interviewee points out:

"Many online media are getting more and more similar to each other because they like to copy from the same source or each other. I think it's a really bad practice in online media. For example, a person wrote an article in a bog or Facebook wall, and then various platforms copied. Actually, these media have the same articles on their platforms, asking permission to copy among them. I do not think it is a good way to maintain media like this because the audience has no choice. We are reading the same thing. Again, you are becoming an encyclopedia." (WK News, June 27, 2019)

Another essential element is that topics such as the prodemocracy protests widely covered by mainstream and other alternative media platforms and widely discussed in society make

B CLIVATGE, número 8

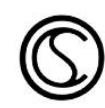


the working class matters invisible. The interviewees recognize the urgency of certain topics regarding the present and future of Hong Kong, but they also call attention to other forgotten realities. For instance, once major pro-democracy protests such as the Umbrella Movement or the Anti-extradition Movement occur in the city, distinct struggles and situations from social groups become more secondary and unnoticed. According to interviewee B:

"The biggest problem is now (at the time of the interview) the extradition law. And after that, it's about the future of Hong Kong and the relationship with China. These are the biggest topics and marginal issues such as labour struggles and the NGOs' work, will be more marginalized by the public. Whether there is a big matter will be fewer people focusing on marginalized topics. The readers will be even less focused on this kind of problems. It will get more marginal." (Radical HK, June 27, 2019)

Therefore, alternative media specialization and time control allows them to dive deep and research the topics they chose to publish. Therefore, they contribute to the visualization of marginalized groups and resisting the self-censorship problem that many journalists face due mainly to the political lines of their media and agenda-setting systems. They also can decide the usefulness of the news based on their mission, not on the readership.

\subsection{Joint resistance}

Alternative media creates a joint resistance with NGOs, both online and offline. Alternative media platforms create an Internet space

B CLIVATGE, número 8

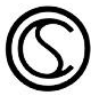


resistance as it has been proved by previous studies in the context of protests and social movements (Castells, 2015; Lee \& Chan, 2015). Besides, alternative media, as a counter-public agent, has been proved to influence online and offline participation (Leung \& Lee, 2014: 352-355), considering that alternative media forms an "alternative public realm" (Downing, 1988), which influences civil society organization. Moreover, people who share similar political views express their ideas to particular matters or news issues online in alternative media sites, which helps to sustain collective action and recruit new participants (Leung \& Lee, 2014: 343-344).

Networked social movements are recreating the public sphere, established around the interaction between local places and Internet networks (Castells 2015, p. 249-316). They start and form on the Internet, but they need to step into the urban space to become visual, to become a movement. The space of autonomy connects networks on the Internet with the occupations occurring in the urban space. It is a dimension of free communication beyond the control of governments and monopolizing corporations. It is in this dimension where alternative media and civic organizations collaborate and reinforce each other to influence those in power and improve their communities. Also, alternative media constructs a persistent and joint resistance that goes beyond the mobilization peaks of social movements, and it is nurtured with the connection to and collaboration with NGOs. This form of resistance follows the proximity between media and civil society. It is also out of the area and economic advantage that mainstream media has regarding the

B Clivatge, número 8

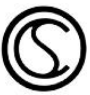


Internet usage acquisition and public influence, mainly due to economic and financial reasons. As pointed out by interviewee A:

"Of course, the capital can still buy a lot of internet space because they (mainstream media) have the way to do the sponsor and to hire a huge number of journalists, but it is also an opened up space for different people to train up their skills and own style instead of everybody have to follow the so-called academic, professional training for journalists. Many of that kind of value (that the capital reproduces) may not be very progressive. It is quite conservative and distant from the people. Since 2014 there is a huge capital input and influence to the Internet media (from Mainland China) and online media, the space for independent media is shrinking. But for us and for another independent journalists, it means that our role is getting more important. Because there are more commercial voices, and that is why independent media should persist." (WK News, June 27, 2019)

Besides, having strong networking with civic organizations is an essential factor for creating and maintaining the online and offline joint resistance, considering that social processes and behaviours could be explained based on the network that connects the different actors (individuals and groups) having common attributes and being immersed in structured social relations (Rodríguez, A. 2005: 10-14). It is well known that social bonds and ties are essential for the reinforcement of civic engagement (Putnam, 2005). It is also a key aspect among media practitioners. However, many of the NGOs covering issues regarding the working class in Hong Kong will not trust conventional media, but they trust

B CLIVATGE, número 8

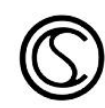


alternative media platforms. Also, the work of alternative media and the NGOs is self-reinforcing. Lee, F. (2019: 170) uses the term "opinion media" to refer to the range of outlets whose main content is constituted by opinions and discourses instead of news and information." (Lee, F., 2019: 170). However, alternative media does not just offer opinion but information since most of the cases follow a specialized study of the news, which, is based on life stories and NGOs data facilitation, as asserted by the interviewees. Interviewee B highlights that:

"The NGOs do the research, but we record the whole press conference and save the report on our website, we create a database. And then we also share it with the NGOs and collaborate with them. We usually focus on marginal issues, for example, related to the worker's labour rights or the fishermen sector (...)." (Radical HK, June 27, 2019)

In the same line, interviewee $\mathrm{A}$ asserts that:

"Of course, we want a larger audience, but we do not make really big efforts to achieve it. We mainly have, besides Facebook posting, three ways to spread. First, it is through the activists NGOs network which we hope that the co-workers NGOs can spread the news to the people they are working. For example, if there is a group, which is organizing workers, they could spread our reports. (...) After several years of reporting we also build up relations with some of these organizations, but more or less it depends on how the public and NGOs organizers want to keep the contact with us or have their way of organizing. (...) The second part is we will join the forums or the Facebook groups of different

B CLIVATGE, número 8

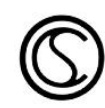


communities like there are groups of drivers groups, of construction workers or sales. We join those groups and then we post those articles. Or there are also some other groups in terms of area. For example, there is a group for HK people in HK Island, and if there is something relevant for that area, we also post that. This kind of spreading information is quite effective because we directly contribute to the target. The third way is also another kind of direct contact. But we do it really rarely that is to print our staff and show it in the community in which that report is written. In the case of cleaning workers, we did some street exhibitions." (WK News, June 27, 2019)

Hence, the collaboration, structured social relations, selfreinforcing dynamics and trust ties between alternative media platforms and civic groups/organizations, is what makes the network and joint resistance stable and cohesive. It also creates proximity among alternative media platforms and civil society.

\section{Concluding discussion}

This paper has explored the role and self-perception of Hong Kong alternative media, considering that it is still an under-researched and under-theorized topic that needs further academic attention as well as, empirical and qualitative analyses; especially regarding East Asia. This study has determined four critical aspects in order to explore alternative media's role: a) the context in which they are surviving, b) their self-perception, c) the reaction from other key actors (audience and mainstream media), and d) the relationship with civic organizations. WK News and Radical HK have young readers, and they mainly reach small audiences from Hong Kong

B CLIVATGE, número 8

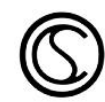


but also, Taiwan, Malaysia and in a lower scale Mainland China. This also could make their role to be more significant, not just on a local scale but also, in a cross-border and international context.

The five patterns explored in this article - the sense of selfidentity, intermediary connections, potential influence on the mainstream media news agenda, specialization and time control and, joint resistance - reflect key aspects of strength, continuation and challenges that are a consequence of the problems and characteristics already present during the first and second waves of alternative media in Hong Kong in 2004 and 2012-2013. These elements are the problem of economic and financial survival and low readership, the self-censorship problem, the contraction of spaces of free expression, the growth of social protests in Hong Kong and the popularization of social media (Lee, F., 2019: 176177; Chan, 2016: 675).

Additionally, there is a lack of alternative media culture in the Hong Kong civil society as well. Many people do not know about the role or even the existence of many alternative media platforms. Besides, considering that Hong Kong has a liberal capitalistic economic system, another substantial challenge rather than authoritarian governments is the free market (Lewis, 1995: 140). Despite all these problems, the alternative media must continue to exploit the potential of the Internet in distributing information and facilitating debate (Ling, 2003: 299). It is also essential to keep building networks of proximity among civil organizations and civil society while keeping their authenticity and commitment. Alternative's media self-identity building and consolidation is

B CLIVATGE, número 8

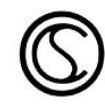


another crucial aspect for their long-term survival and adds value to Hong Kong civil society. Having a small readership is part of the nature of alternative media being by definition, non-mainstream, considering that their significance and the political arena lies in its "alternative" nature (Yung \& Leung, 2014: 99).

Alternative media development and its rise are related to the socio-political situation and processes of democratization (Lee C. 2003: 172; Iam-chong, 2009; Lee F., 2019), being "a crucial source of critical and pro-democracy commentaries" (Lee F., 2019: 177178). The question is now if we are entering a third wave of alternative media in Hong Kong. One thing seems clear: alternative media has a role in "opening up media spaces and ushering in the processes of political democratization" (Lee, C. 2003: 164), combining elements of identity, commitment and civic engagement as well as, particular values and principals, focusing on struggles by marginalized groups such as the working-class. On the other hand, although the Basic Law theoretically guarantees press and media freedom in Hong Kong, the decrease of the power of press freedom in the last decade should be a topic of local, national and international concern. Three sectors, progressive alternative media, professional and liberal-oriented media and civil society could slow down the decline of media freedom by working together and collaborating (Lee, F., 2019: 181-182).

The author acknowledges the limitations regarding the sample selection, representativeness and interpretation. However, these limitations do not diminish the importance of the core argument of this paper. Alternative media plays an essential role in the context

B CLIVATGE, número 8

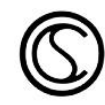


of socio-political transformation and social unrest, especially with the seriousness of the issue of decreasing press and media freedom. It also helps to understand the changing media landscape and the invisibility of certain groups of the Hong Kong civil society. This study has various contributions being a call for theory development in the field of media and political communication studies as well as social movements. The exploration from different angles presented contributes to theoretical, conceptual and empirical developments, and it can be applied to other cases.

It is difficult to be optimistic about the future of online alternative media and press and media freedom in Hong Kong. However, alternative media should be recognized by politicians and communication policy planners because "they are at the centre of numerous fights in favour of democratic functioning." (Lewis, 1995: 140). Besides, the interrelation between alternative media, mainstream media and civil society groups should be reinforced as well. The role of alternative online media is vital in Hong Kong because there is not democratic self-government. It is thus, a way to inform the public regarding marginalized issues and access to alternative voices and perspectives. It is also a way to express dissatisfaction and a significant arena for political participation.

B CLiVATGE, número 8

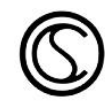




\section{References}

Almond, G. and Verba, S. (1963). The Civic Culture: Political Attitudes and Democracy in Five Nations. New Jersey: Princeton University Press.

Ambrosi, A. (1991). "Introduction: Alternative Communication and Development Alternatives", in Thede, N. and Ambrosi, A. (eds.) (1991). Video the Changing World. Montreal: Black Rose Books.

Atton, C. (2002). Alternative Media. London: SAGE Publications.

Castells, M. (2010). The Power of Identity. Malden, MA: WileyBlackwell.

Castells, M. (2015). Networks of Outrage and Hope. Social Movements in the Internet Age. Cambridge: Polity Press.

Chan, M. (2017). "Media Use and the Social Identity Model of Collective Action: Examining the Roles of Online Alternative News and Social Media News." Journalisms \& Mass Communication Quarterly. 94 (3): 663-81.

Coleman, R. et al. (2009). "Agenda-Setting." In: Wahl-Jorgensen, K. and Hanitzsch, T. (eds.). The Handbook of Journalism Studies. New York: Routledge.

Creswell. J. (2007). Qualitative Inquiry \& Research Design. Choosing Among Five Approaches. Thousand Oaks: Sage Publications.

Dearing, J. and Rogers, E. (1996). Communication Concepts: Agendasetting. Thousand Oaks: Sage.

B CLIVATGE, número 8

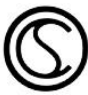


DeGeorge, W. (1981). "Conceptualization and measurement of audience agenda", in Wilhoit, G. and DeBeck, H. (eds.) (1981). Mass communication review Yearbook 2. Beverly Hills: Sage.

Downing, J. (1988). "The Alternative Public Realm: The Organization of the 1980s Anti-nuclear Press in West Germany and Britain." Media, Culture \& Society. 10 (2): 163181.

Downing, J. (2001). Radical Media. Rebellious Communication and Social Movements. Thousand Oaks: Sage Publications.

Fong, B. (2017). "In-between liberal authoritarianism and electoral authoritarianism: Hong Kong's democratization under Chinese sovereignty, 1997-2016." Democratization. 24 (4): 724-750

Government of Hong Kong SAR (2019). Hong Kong: The facts. Employment. Labour Department. Available at: https://www.gov.hk/en/about/abouthk/factsheets/docs/e mployment.pdf

Harcup, T. (2013). Alternative Journalism, Alternative Voices. New York: Routledge.

Harlow, S. (2017). "Recognizing the importance of alternative media. Role perceptions and journalistic culture in Brazil." Journalism Studies. 20 (1).

Iam-Chong, I. (2009). "Hong Kong: The Rise of a New Political Force." In Oi-Wan, L. and Iam-Chong, I. (eds.) (2009). Info Rhizome. Report on Independent Media in the Chinesespeaking World (2008/09). Hong Kong: In-Media.

B CLIVATGE, número 8

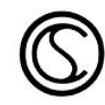


Krueger, B. (2006). "A Comparison of Conventional and Internet Political Mobilization." American Politics Research. 34 (6): 759-776.

Lam, Wai-man (2018). “Hong Kong's Fragmented Soul. Exploring Brands of Localism", in Wai-man L. and Cooper, L. (eds.) (2018) Citizenship, Identity and Social Movements in the New Hong Kong: Localism after the Umbrella Movement. London: Routledge.

Law, W.-S. (2017). “Decolonisation deferred: Hong Kong Identity in Historical Perspective", in W. Lam and L. Cooper (eds.) (2017) Citizenship, identity and social movements in the new Hong Kong: Localism after the Umbrella Movement. New York: Taylor and Francis.

Lee, C. "Liberalization without Full Democracy. Guerrilla Media and Political Movements in Taiwan", in Couldry, N. and Curran, J. (eds.) (2003). Contesting Media Power. Alternative Media in a Networked World. Lanham: Rowman \& LittleField Publishers.

Lee, F. (2015). "Internet Alternative Media Use and Oppositional Knowledge." International Journal of Public Opinion Research, 27 (3): 318-340

Lee, F., and Chan, J. (2015). "Digital Media Use and Participation Leadership in Social Protests: The Case of Tiananmen Commemoration in Hong Kong." Telematics and Informatics. 32 (4): 879-89. 
Lee, F. (2019). "Opinion Media. From Talk Radio to Internet Alternative Websites." In Lui T., Chui S. and Yep R. (eds.) (2019) Routledge Handbook of Contemporary Hong Kong. Oxon: Routledge.

Leung, D.K. and Lee, F.L. (2014). "Cultivating an Active Online Counterpublic: Examining Usage and Political Impact of Internet Alternative Media." International Journal of Press/Politics, 19 (3): 340-359.

Lewis, P.M. (1995). Medios de Comunicación Alternativos: La Conexión de lo Mundial con lo Local. London: UNESCO Publishing.

Ling, S. (2003). "The Alternative Media in Malaysia: Their Potential and Limitations", in Couldry, N. and Curran, J. (eds.) (2003). Contesting Media Power. Alternative Media in a Networked World. Lanam: Rowman \& LittleField Publishers.

Meyers, O. (2008). Contextualizing Alternative Journalism: Haolam Hazeh and the Birth of Critical Israeli Newsmaking. Journalism Studies, 9 (3), 374-391.

Ngok, Ma (2018). "Changing Identity Politics. The Democracy Movement in Hong Kong. In Wai-man L. and Cooper, L. (eds.) (2018) Citizenship, Identity and Social Movements in the New Hong Kong: Localism after the Umbrella Movement. London: Routledge.

Oller, A.M. (2014). "The triangle formed by framing, agenda-setting and metacoverage." Anuario Electrónico de Estudios en Comunicación Social, 7 (1).

B CLIVATGE, número 8

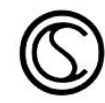


Ortmann, S. (2018). "The development of Hong Kong identity. From local to national identity", in Wai-man L. and Cooper, L. (eds.) (2018) Citizenship, Identity and Social Movements in the New Hong Kong: Localism after the Umbrella Movement. London: Routledge.

Putnam, R. (1993). Making Democracy Work. Civic Traditions in Modern Italy. Princeton: Princeton University Press.

Rodríguez, J.A. (2005). Análisis estructural y de redes. Cuadernos Metodológicos (16). Madrid: Centro de Investigaciones Sociológicas.

Rodríguez, R. (2004). Teoría de la Agenda-Setting. Aplicación a la Enseñanza Universitaria. Alicante: OBETS Editorial.

Saldaña, J. (2009). The Coding Manual for Qualitative Researchers. London: SAGE Publications.

Song, X. (2009). Between Civic and Ethnic. The Transformation of Taiwanese Nationalist Ideologies (1895-2000). Bussells: Uitgeverij VUBPRESS Brussels University Press.

Stroud, N. (2011). Niche News. The Politics of New Choice. New York: Oxford University Press.

Tang, G. (2019). "Social Media and Social Mobilization", in Lui T., Chui S. \& Yep R. (eds.) (2019) Routledge Handbook of Contemporary Hong Kong. Oxon: Routledge. pp.185-198.

Wai-man, L. and Luke C. (2018). Citizenship, Identity and Social Movements in the New Hong Kong. Localism After the Umbrella Movement. Oxon: Routledge.

B CLIVATGE, número 8

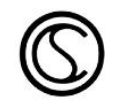


Weaver, D., McCombs, M. and Spellman, C. (1975). "Watergate and the media: A case study of agenda-setting." American Politics Quarterly, 3: 458-472.

Yung, B., and Leung, L. (2014). "Diverse Roles of Alternative Media in Hong Kong Civil Society." Journal of Asian Public Policy. 7 (1): 83-101.

Zhao, S. (2019, March 21). Lantau Tomorrow Vision is arguably Hong Kong's most important and controversial project. Here's what you need to know about HK\$624 billion plan. South China Morning Post.

\footnotetext{
.

(C) del artículo, los/as autores/as

Este texto está protegido por una licencia ReconocimientoCreativeCommons 4.0.

Usted es libre decompartir -copiar y redistribuir el material en cualquier medio o formato- y adaptar el documento - remezclar, transformar y crear a partir del material- para cualquier propósito, incluso comercialmente, siempre que cumpla la condición de:
}

Atribución: Usted debe reconocer el crédito de una obra de manera adecuada, proporcionar un enlace a la licencia, e indicar si se han realizado cambios. Puede hacerlo en cualquier forma razonable, pero no de forma tal que sugiera que tiene el apoyo del licenciante o lo recibe por el uso que hace. 